\section{Methodological aspects of the assessment of dietary intake in the Brazilian National Survey on Child Nutrition (ENANI-2019): a population- based household survey}

\author{
Aspectos metodológicos da avaliação do \\ consumo alimentar no Estudo Nacional de \\ Alimentação e Nutrição Infantil (ENANI-2019): \\ inquérito domiciliar de base populacional
}

\author{
Aspectos metodológicos de la evaluación del \\ consumo alimentario en el Estudio Nacional de \\ Alimentación y Nutrición Infantil (ENANI-2019): \\ encuesta domiciliaria de base poblacional
}

Elisa Maria de Aquino Lacerda 1 Cristiano Siqueira Boccolini 2 Nadya Helena Alves-Santos 1 Inês Rugani Ribeiro de Castro 3 Luiz Antonio dos Anjos 4 Sandra Patricia Crispim 5 Teresa Helena Macedo da Costa 6 Milena Miranda de Moraes Ferreira 7 Dayana Rodrigues Farias 1 Leticia Barroso Vertulli Carneiro 1 Talita Lelis Berti 1 Gilberto Kac 1

doi: 10.1590/0102-311X00301420

\begin{abstract}
This manuscript aims to describe the methodological, operational, and quality control aspects of the assessment of dietary intake in children under five years of age participating in the Brazilian National Survey on Child Nutrition (ENANI-2019), a household survey in a probability sample of Brazilian households. Two instruments were developed to assess child feeding practices - a structured, current status-type questionnaire and a 24-hour dietary recall (24HR), both installed in a mobile data collection device used by previously trained interviewers. A Photographic Manual for Quantification of Children's Dietary Intake was specifically developed for and used in the survey as a support aid to identify and quantify foods reported in the 24HR. During the fieldwork, continuous quality control of the records was performed. Data errors or incomplete data in the system were corrected, and the fieldwork team was systematically contacted and informed on their performance, with reiterated orientation on data collection. All children in the sample were evaluated with the two instruments, but data were obtained from the structured questionnaire on all children in the sample $(n=14,558)$ and $24 \mathrm{HR}$ on 14,541 children. ENANI-2019 developed innovative methods and materials based on the Brazilian and international literature to address knowledge gaps on underfive children's dietary intake. Unprecedented results will be produced, which will allow updating food and nutrition guidelines for children under five years of age in Brazil.
\end{abstract}

Food; Infant; Child; Breast Feeding; Diet Surveys

\author{
1 Instituto de Nutrição Josué de Castro, Universidade \\ Federal do Rio de Janeiro, Rio de Janeiro, Brasil. \\ 2 Instituto de Comunicação e Informação Científica e \\ Tecnológica em Saúde, Fundação Oswaldo Cruz, Rio de \\ Janeiro, Brasil. \\ 3 Instituto de Nutrição, Universidade do Estado do Rio de \\ Janeiro, Rio de Janeiro, Brasil. \\ 4 Departamento de Nutrição Social, Universidade Federal \\ Fluminense, Rio de Janeiro, Brasil. \\ 5 Departamento de Nutrição, Universidade Federal do \\ Paraná, Curitiba, Brasil. \\ 6 Faculdade de Ciências da Saúde, Universidade de Brasília, \\ Brasília, Brasil. \\ 7 Faculdade de Ciências da Nutrição e Alimentação, \\ Universidade do Porto, Porto, Portugal. \\ Correspondence \\ G. Kac \\ Departamento de Nutrição Social e Aplicada, Instituto de \\ Nutrição Josué de Castro, Universidade Federal do \\ Rio de Janeiro. \\ Av. Brigadeiro Trompowsky s/ $n$, Bloco J, 20 andar, \\ Rio de Janeiro, RJ 21941-590, Brasil. \\ gilberto.kac@gmail.com
}




\section{Introduction}

At least one out of three children under five years of age in the world presents stunting, underweight, or overweight, and more than $50 \%$ suffer from micronutrient deficiencies, the consequences of which include growth and development deficits, reduced immunity, blindness, and increased risk of death 1 . Thus, early childhood feeding plays a crucial role in preventing these problems and reducing child morbidity and mortality 2,3, decreasing the global burden of diseases 4 and contributing to the establishment of healthy dietary behaviors in subsequent years 5,6.

Brazilian studies on under-five food and nutritional surveillance are among the main strategies for monitoring feeding practices and nutritional status. They are essential for backing the development, evaluation, and redirection of food and nutrition policies. These were assessed in national household surveys such as the Brazilian Family Budget Survey (ENDEF) in 1974, the first survey on food and nutritional status of the Brazilian population, the Brazilian National Demographic and Health Survey (PNDS) of 1986, 1996, and 2006, and the Brazilian National Health Survey (PNS) of 2013, which provided evidence on breastfeeding and children's dietary intake 7,8 . However, the long interval between these epidemiological surveys and the study design of the PNS survey in 2013, planned to assess the adult population, hindered monitoring the evolution of food and nutrition indicators in Brazilian children 7,8,9,10.

Given this scenario, the Brazilian Ministry of Health financed a population-based household survey of children under five years of age. The Brazilian National Survey on Child Nutrition (ENANI-2019) aimed to evaluate the epidemiology of feeding practices, anthropometric nutritional status, and micronutrient deficiencies according to major geographic regions of the country. This is the first national household survey in which under-five dietary intake was assessed in detail at the individual level. ENANI-2019 was organized according to three components: (I) assessment of breastfeeding and dietary intake; (II) anthropometric assessment of nutritional status; and (III) assessment of micronutrient deficiencies. This article describes the methodological, operational, and quality control aspects related to the instruments developed and applied for data collection on feeding practices and dietary intake, namely a structured questionnaire and a 24-hour dietary recall (24HR).

\section{Methods}

\section{Establishment of the domain's expert group}

During the elaboration of the project, an expert group was established, consisting of professors from public universities in various regions of Brazil, experts in the areas of breastfeeding, complementary feeding, and dietary intake. The group was responsible for planning this survey domain, determining and developing the instruments, conducting the training, monitoring data collection, and planning the cleaning and organization processing of the data. The group was joined by young undergraduate and graduate students, and research assistants.

\section{Study design, population, and sampling}

ENANI-2019 is a population-based household survey. A sample of 15,000 households was designed, distributed across 123 municipalities in Brazil's 26 states and the Federal District. The sample was designed to generate estimates for the five major geographic regions, with the weights calibrated by the child's age group and sex. Details of the sampling design are available in Vasconcellos et al. 11.

The study was approved by the Institutional Review Board of the Clementino Fraga Filho University Hospital of the Federal University of Rio de Janeiro (CAAE 89798718.7.0000.5257). Data were collected after obtaining the signature of two copies of the informed consent form of the child's parent or guardian, who received one of the signed copies. The methods employed in the overall development of ENANI-2019 and those used in domains II and III are described in detail elsewhere in specific publications $11,12,13,14$. 


\section{Structured questionnaire for evaluation of child feeding practices}

This questionnaire was part of the overall questionnaire and was developed using the software Census and Survey Processing System (CSPro; https://www.census.gov/data/software/cspro.html). This instrument consisted of 40 questions. It was drafted to allow the development of indicators for feeding practices in children under two years of age, proposed by the World Health Organization (WHO) 15 , and other indicators based on recommendations by the Brazilian Ministry of Health. These comprised the timely introduction of foods, food diversity, supply of dietary sources of vitamin A and iron, and consumption of ultra-processed foods 16 . Box 1 presents the list of foods and other aspects of child feeding in the ENANI-2019 questionnaire.

Questions were also drafted that allowed the creation of unprecedented practices related to maternal breastfeeding, such as cross-breastfeeding 17 , breast milk donation to human milk banks 18 , exclusive breastfeeding during the hospital stay, and use of prelacteal feedings 19 . The complete questionnaire is available on the ENANI website (https://enani.nutricao.ufrj.br/index.php/materiais/).

\section{4-hour dietary recall}

Application of the 24HR 20 used the multiple-pass method recommended by the United States Department of Agriculture (USDA) 21, the structure of which was incorporated into an application developed for this purpose - the 24HR Application Software (24HR-App). A photographic manual for quantification of children's dietary intake was specifically developed for the survey, which supported identifying and estimating the amounts of foods consumed by the child during application of the 24HR 22 .

\section{- The 24HR-App}

The 24HR-App was commissioned and developed under the supervision of the Executive Committee and the expert group from the domain on maternal breastfeeding and under-five dietary intake. Programmed for the Android Studio platform in Java language, the App is compatible with mobile devices that use Android version 5.0 or higher. The 24HR-App functions offline, but Internet access allows installing and updating the databases and sending the collected data to the server. The App was installed and integrated into the overall survey questionnaire, and its database corresponds to the interaction of six lists (Box 2). In addition, a specific manual was prepared with details on the use of the 24HR-App, and the online version was installed in the mobile data collection device (MDC) for real-time access during data collection. At the end of the survey, an open-access version of the 24HRApp was developed for free use. The installation file and manual are available for free download at https://enani.nutricao.ufrj.br/index.php/materiais/.

\section{- Photographic Manual for Quantification of Children's Dietary Intake}

The Photographic Manual for Quantification of Children's Dietary Intake displays photos of 101 foods, 81 household measures, and 27 food forms 22 and is available for download at https://enani.nutri cao.ufrj.br/wp-content/uploads/2019/06/Manual-quantificacao-alimentar-infantil-BR.pdf. Figure 1 summarizes the stages in its development. Initially, a list of foods consumed by children under five years of age was created, based on studies in Brazil's five major geographic regions. Foods consumed by adults were also included, assuming that children could also consume them, since they explain the variability in the consumption of energy, macronutrients, iron, calcium, and vitamin A and vitamin C among individuals, considering data from the POF of 2008/2009 23. Later, the foods that required photos for their quantification were determined (e.g., amorphous foods such as pasta; foods served in non-uniform pieces such as meats), adopting international guidelines for producing photos 24 .

The lists of foods, household measures, and food forms had their face validity analyzed by experts. This analysis consists of subjective judgment on the degree to which items in a measure are relevant and representative of a given construct 25 . Suggestions were incorporated on the inclusion/exclusion of foods, measures, and formats, enhancing the food description since they displayed synonymy and homonymy with the food in the respective region. Foods with similar formats and from the same food 
Box 1

List of foods and additional data that comprised the section on children's feeding. Brazilian National Survey on Child Nutrition (ENANI-2019).

FOODS AND ADDITIONAL DATA THAT COMPRISED THE SECTION ON CHILDREN'S FEEDING

\section{Water and milk}

-Water. Filtered or boiled water. Water with sugar

- Tea

- Breastmilk

- Infant formula

- Powdered cow's milk, liquid cow's milk

- Powdered soy milk, liquid soy milk

- Porridge or oatmeal with milk

- Yogurt

\section{Juices and fruits}

- Natural pressed juice without added sugar

-Whole fruit in pieces or mashed; frequency

- Mango, papaya, or guava (foods high in vitamin A)

\section{Regular family foods and cereals}

- Regular family foods (straight from the pan, puree, or soup). Frequency. Consistency (pieces or whole, mashed, strained, blended, or only broth)

- Rice, potato, yam, water yam, cassava/manioc, flour, or pasta (except instant noodles)

- Bread, rolls, homemade, industrialized

- Vegetables other than potato, yam, water yam, cassava/manioc

- Carrot, squash, pumpkin, or sweet potato (foods high in vitamin A)

- Kale, spinach, taro, broccoli, purslane, portulaca, mustard greens (foods high in vitamin A or iron)

- Greens other than kale, spinach, taro, broccoli, purslane, portulaca, mustard greens

- Beans and other grains, such as lentils, peas, or garbanzos (chickpeas)

- Meat (beef, chicken, pork, fish, or other)

- Liver

- Egg (fried, scrambled, omelet, boiled, or blended)

\section{Ultra-processed foods}

- Hamburger, ham, baloney, salami, nuggets, sausage, hotdogs

- Packaged salty snacks such as chips, Fandangos, Cheetos etc.

- Industrialized juices in cartons, coconut water in cartons, natural guarana or guarana syrup, currant drink, powdered fruit juice, natural fruit juice with added sugar

- Soda

- Instant noodles

- Cookies, crackers

- Candy, lollipops, and other sweets

- Industrialized seasonings (e.g., Sazon, Knorr)

- Instant rice flour, corn meal, wheat flour, or oatmeal

Food consumed in baby bottles or small baby bottles

Food sweetened with sugar, honey, or molasses

Note: the questions referred to what the child had consumed the previous day, where the options were "yes", "no", "doesn't know/doesn't want to answer". The complete questionnaire is available at ENANI-2019 website (https://enani.nutricao.ufrj.br/index.php/materiais/). 
Box 2

Items in the database of the 24 hour-dietary recall App. Brazilian National Survey on Child Nutrition (ENANI-2019).

\begin{tabular}{|c|c|c|}
\hline ITEMS & \multicolumn{2}{|c|}{ DESCRIPTION } \\
\hline Foods and preparations & \multicolumn{2}{|c|}{$\begin{array}{l}\text { List of foods and preparations consumed by the Brazilian population and are part of Brazilian children's food } \\
\text { habits. It consists of 2,960 items, drafted according to the compilation of the data used in the National Food Survey/ } \\
\text { POF (2008-2009) 23, foods from the stages in the development of the Photographic Manual for Quantification of } \\
\text { Children's Dietary Intake 22, in addition to other items from a survey in children } 6 \text { to } 59.9 \text { months of age in the city } \\
\text { of Rio de Janeiro in } 2014 \text { (unpublished data). Experts from the field of nutrition in Brazil's five major geographic } \\
\text { regions were consulted on the inclusion of typical and commonly consumed regional foods. Other foods were } \\
\text { identified during the interviewers' training. After inclusion, the interviewers uploaded the new version of the App } \\
\text { without interfering with the previously completed 24HRs. }\end{array}$} \\
\hline Type of meal & $\begin{array}{l}\text { - } \text { Breakfast } \\
\text { - } \text { Morning snack } \\
\text { - } \text { Lunch } \\
\text { - } \text { Afternoon snack } \\
\text { - } \text { Dinner }\end{array}$ & $\begin{array}{l}\text { - } \text { Supper or evening snack } \\
\text { - } \text { Nibbling or quick snacks } \\
\text { - } \text { Midnight snack } \\
\text { - }\end{array}$ \\
\hline Preparation & 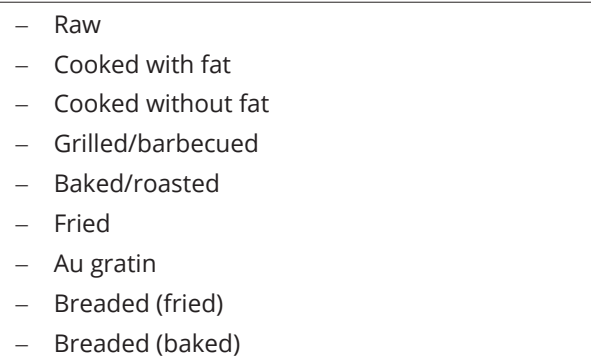 & $\begin{array}{l}\text { - Sauteed } \\
\text { - Stew } \\
\text { - Steamed } \\
\text { - Microwave } \\
\text { - Tomato sauce } \\
\text { - White sauce } \\
\text { - Garlic and olive oil } \\
\text { - With butter or vegetable oil }\end{array}$ \\
\hline Addition & 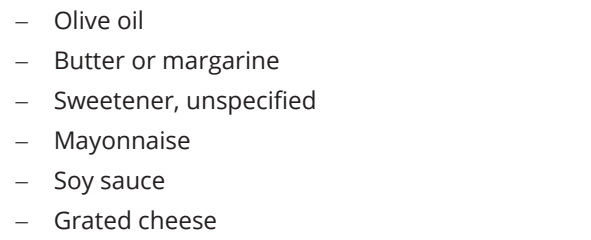 & $\begin{array}{l}\text { - } \text { Cream/whipped cream } \\
\text { - } \text { Condensed milk } \\
\text { - Granola } \\
\text { - Syrups, sauces } \\
\text { - }\end{array}$ \\
\hline Meal place & $\begin{array}{l}\text { - Child's home, relatives' home, or friends' home } \\
\text { - Daycare center/school }\end{array}$ & $\begin{array}{l}\text { - Restaurants/snack bars } \\
\text { - Street (city squares, parks, physician's office, etc.) }\end{array}$ \\
\hline Units & \multicolumn{2}{|c|}{$\begin{array}{l}\text { The App presents } 804 \text { options of units to describe the amounts reported (utensils, photos from the photographic } \\
\text { manual, household measures, standard servings, and units of foods). }\end{array}$} \\
\hline
\end{tabular}

24HR: 24-hour dietary recall; POF: Brazilian Family Budgets Survey.

Source: prepared by the authors based on the methodology explained in the Photographic Manual for Quantification of Children's Dietary Intake 22.

group (e.g., potato and sweet potato) featured only one photo to estimate the different foods' volume. Based on the foods' volume and density; it was possible to estimate their mass.

Each food has four to six photos representing under-five children's dietary intake. The intake quantification of foods with a well-defined shape, such as bread, was obtained with the help of pictures of food shapes. Some of these were based on illustrations from the GloboDiet food quantification manual from Switzerland 26 and France 27. The pages with photos of household measures and food shapes include a ruler in real scale for interviewees to estimate the portion sizes based on the photos present in the manual. In mass or volume units, the amounts of measures and portions are described at the end of the manual, showing the picture of a $27 \mathrm{~cm}$ plate on an $\mathrm{A} 3$ page, coupled with the back cover (Figure 2). 


\section{Figure 1}

Stages in the development of the Photographic Manual for Quantification of Children's Food Consumption. Brazilian National Survey on Child Nutrition (ENANI-2019).

\section{List of foods}

List of foods most widely consumed by children under five years of age from eight studies in the states of Acre, Maranhão, Paraná, Rio Grande do Sul, Rio de Janeiro, Pernambuco, and São Paulo, and in the Federal District.

Definition of foods and units to be photographed

Definition of foods and units that require photographs to assist their quantification.

\section{Face validity}

Face validity analysis of the list of foods, household measures, and forms by 17 specialists in food consumption evaluation in Brasil's five major geographic regions.

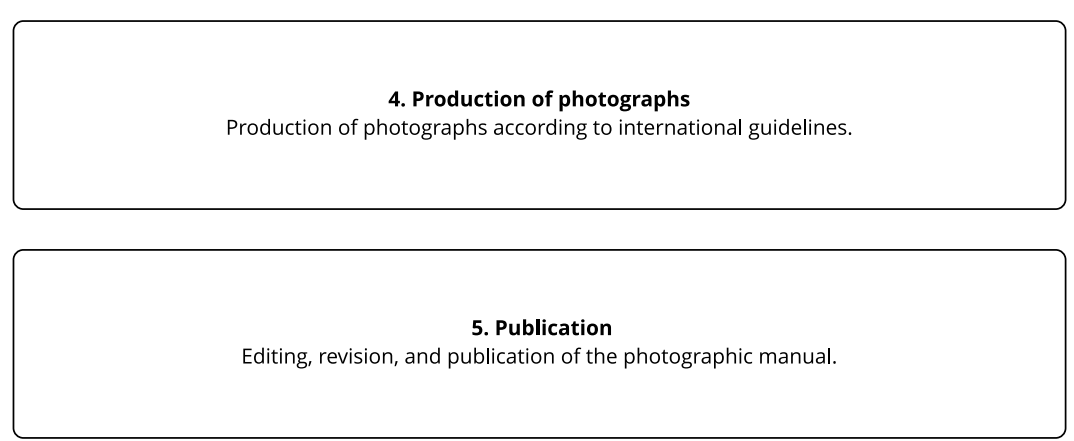

Source: prepared by the authors based on the methodology explained in the Photographic Manual for Quantification of Children's Dietary Intake 22.

\section{Training of interviewers}

The training, described in detail by Alves-Santos et al. 12, was administered in seven Brazilian state capitals, where the training team and interviewers convened. The training content on the $24 \mathrm{HR}$ included a description of the method, instructions on the interviewer's attitudes, procedures for search and inclusion of foods in the 24HR-App, completion of the $24 \mathrm{HR}$, use of the photographic manual, and procedures for dealing with specific situations such as breastfeeding and lack of knowledge on the amount consumed by the child. In addition to lecture-format classes with dialogue, the training included videos, exercises, and simulation. This content was administered in face-to-face classes by one of the coordinators of the domain on evaluation of breastfeeding and children's dietary intake, with the collaboration of the Executive Committee. It lasted 16 hours (two days). The training was evaluated via direct observation of the interviewers' performance. 


\section{Figure 2}

Examples of pages with kitchen utensils and food portions in the photographic manual 22. Brazilian National Survey on Child Nutrition (ENANI-2019).

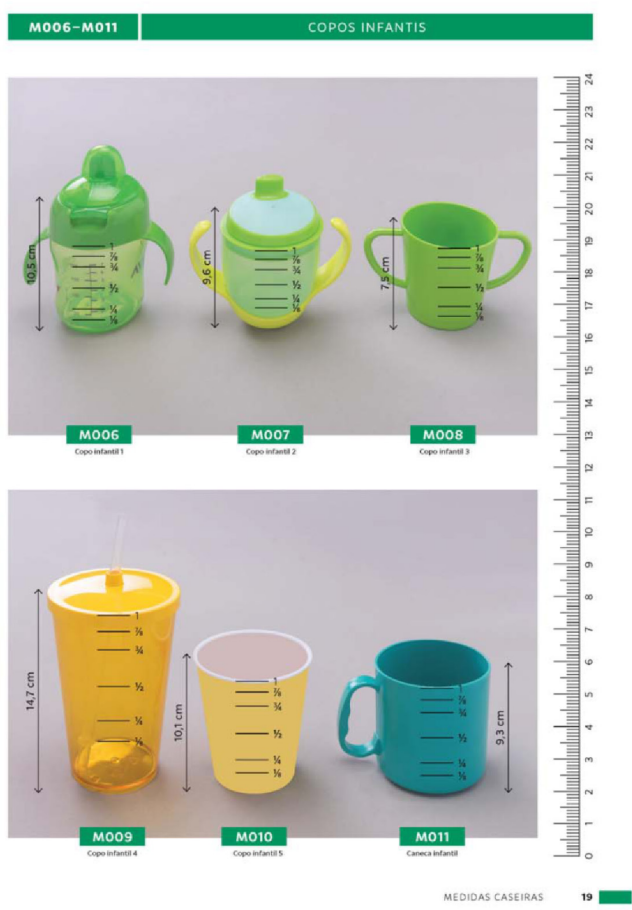

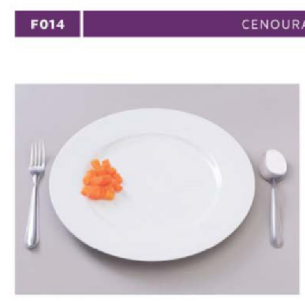

F014 - 1

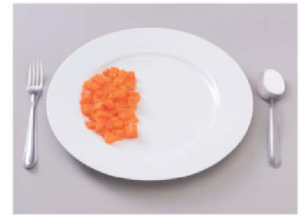

$\mathrm{F} 014-3$

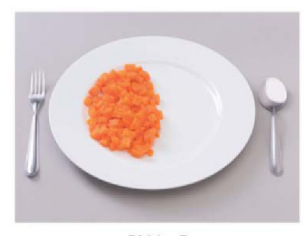

F $014-5$

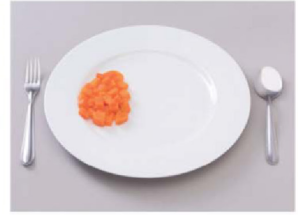

F014 - 2

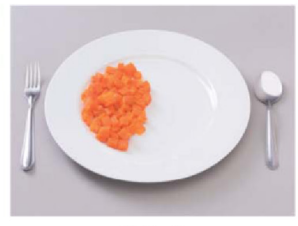

$014-4$

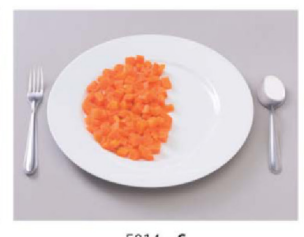

F014- 6

\section{Application of the 24HR in the households}

The 24HR was applied by an interviewer with the mother or another caregiver who knew about the child's diet. At the start of the interview, the respondent stated whether the previous day had been usual in terms of the child's diet, and, regardless of the response, the $24 \mathrm{HR}$ was performed. At the start of each step, the interviewer read a message about what would be requested in that stage.

In Step 1, the interviewer asked for a spontaneous report by the interviewee on the foods consumed. It was not necessary to record times and amounts. If the interviewee reported the child's consumption of a given food preparation, she/he was asked how it was prepared and provided a list of the separate ingredients. Whenever a food was not located in the App, having exhausted all the possible searches, it was included as a new food. Step 2 consisted of six questions on foods frequently forgotten in a 24HR (coffee, tea, soda, juice, breast milk, candy, chewing gum, dessert, cookies, fruit, bread, sugar, honey, other sweetening products, and other foods, beverages, or food complements), with yes-or-no answers. Whenever the interviewee remembered some food, the 24HR-App returned to Step 1 to include it. In Step 3, the time and type of meal were completed for each food included in Step 1. Step 4 featured details on the food: type of preparation, the addition of foods, place where the meal was eaten, and amount/unit consumed. If the food was breastmilk, it was possible to record the duration of the breastfeeding in minutes. This step also included a field for "Observations" in which the interviewer could freely comment on the food that was being described. The 24HR-App presented an alert system that informed on the completeness of the information on foods. Step 5 consisted of verifying the information and data completeness (Figure 3). 
Figure 3

Stages in the data collection in the 24-hour dietary recall App developed for the Brazilian National Survey on Child Nutrition (ENANI-2019).

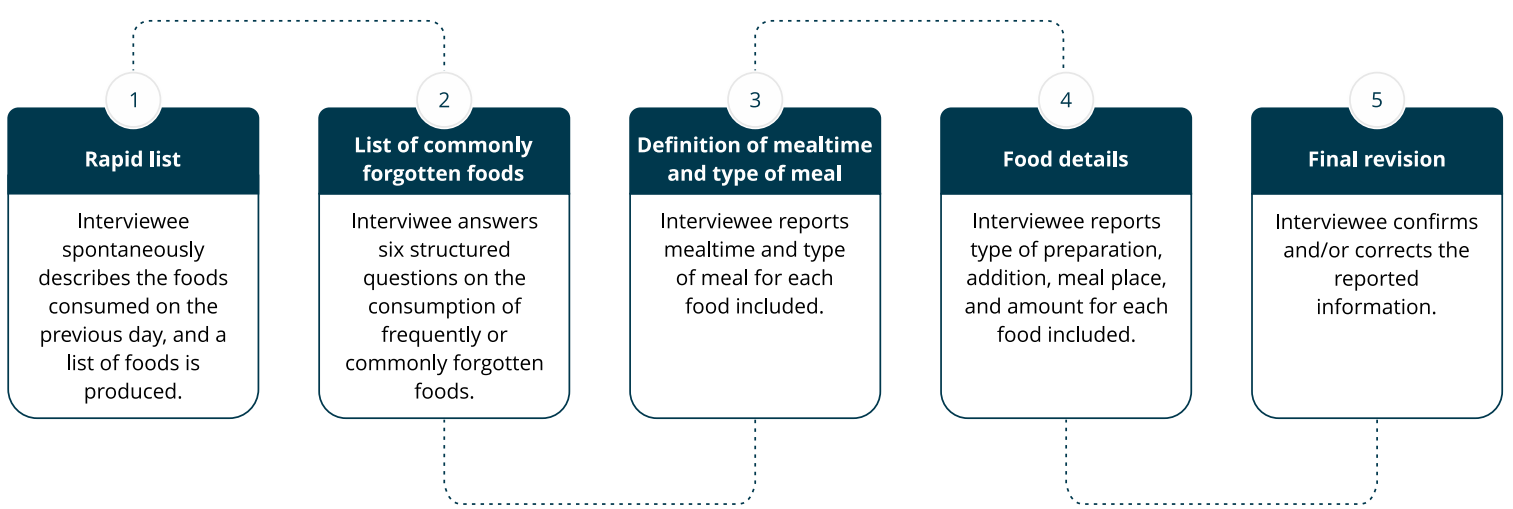

Source: prepared by the authors based on the recommendations from the multiple-pass method recommended by the U.S. Department of Agriculture 21 .

\section{Quality control}

Weekly quality control was performed by the data analysts and reviewed by the domain team coordinator to monitor the questionnaires' completion and assess the records' quality. Monitoring the questionnaire on feeding practices consisted of identifying the percentages of missing data or with answers "doesn't know/doesn't want to answer". Inadequate "skips" on questions and consistency of responses were also evaluated. Weekly reports were submitted to the Executive Committee of ENANI-2019 to discuss and implement solutions, such as reinforcement of data collection procedures with the interviewers through instant messages via WhatsApp and improving the data entry system (Figure 4).

Evaluation of the quality of the $24 \mathrm{HR}$ completion was monitored with two strategies. The first consisted of listing the frequencies of the "food", "preparation", "addition", "amount", and "unit" variables. The list of "food" frequencies allowed monitoring the interviewers' performance in searching for foods in Step 1. The evaluation of frequencies of "preparations", "additions", and "meal places" aimed to locate uncompleted items. The assessment of frequencies of amounts according to given units allowed verifying the completion's consistency (e.g., "120 cups" when the correct information might have been $120 \mathrm{~mL}$ ), besides identifying "inliers" and "outliers" (extreme values inside or outside the interval of expected values, respectively). The second strategy was the qualitative evaluation of 24HRs, considering each child, with the interviewer's identification, to monitor the completion's adequacy. This evaluation was followed by communication with the fieldwork coordinators, supervisors, and interviewers, and procedures were adopted to minimize errors during the fieldwork (Figure 4).

\section{Cleaning and organization of the database from the $24 \mathrm{HR}$}

After receiving the complete $24 \mathrm{HR}$ database, an analysis of the variables' consistency was performed, besides cleaning the database, reading the "observations" field to identify other information on the foods' details, identifying the missing data, and determining the data to be imputed. Errors identified in the database were corrected according to pre-established criteria, and when it was impossible to correct them, they were submitted to imputation.

The household units and measures will be converted into mass and volume, using, in the following order, the Table of Measures Reported for Dietary Intake in Brazil 28, Table for the Evaluation of Dietary Intake in Household Measures 29, and the list of household measures used in the study Food and 


\section{Figure 4}

Procedures used during the fieldwork to improve the quality of completion of the 24-hour dietary recall (24HR). Brazilian National Survey on Child Nutrition (ENANI-2019).

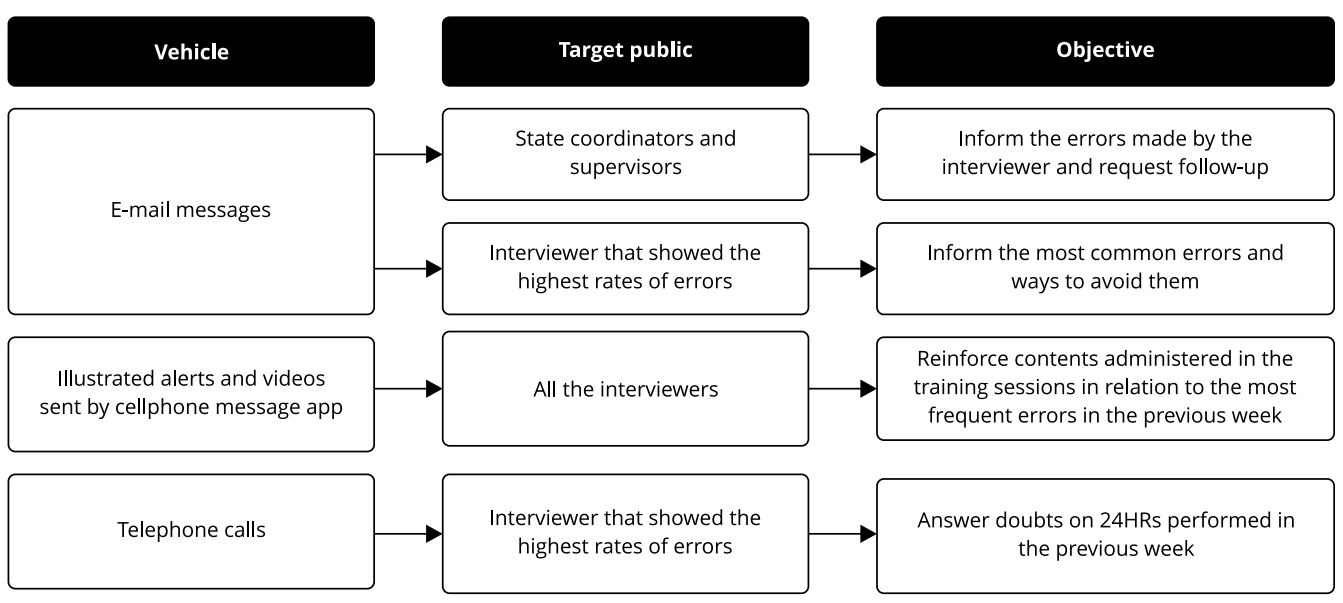

Nutrition of Preschoolers under the Unified Health System (unpublished data). The description of all the procedures in the organization and correction of the database are to be made readily available on the ENANI-2019 website.

The foods' centesimal composition table will be version 7.0 of the Brazilian Food Composition Table (TBCA) 30, which contains information on 34 nutritional components from more than 4,600 foods, including the list of foods from the National Food Survey/POF 2008-2009, with the analyses conducted by the team. Other sources may be consulted if the food is not found in the TBCA. For enriched dairy products and infant food products, the composition informed by the manufacturer on its website will be used.

\section{Results}

Data collection lasted from March 2019 to March 2020, and the sample consisted of 14,558 children and 12,524 households ( $83.5 \%$ of the projected sample). This number, lower than planned, resulted from the interruption of the survey due to the COVID-19 pandemic. Information was obtained for all the children with structured questionnaires. Since most of the variables involved mandatory completion, the occurrence of missing data was considered low, less than $0.1 \%$.

A total of $14,54124 \mathrm{HRs}$ were used, $97.4 \%$ of which on days when the child's foods targeted in the survey were reported as usual. The median time for application of the $24 \mathrm{HR}$ was 14.4 minutes (interquartile range $[\mathrm{IQR}]=12.5)$. The median time was 7.3 minutes $(\mathrm{IQR}=8.2)$ in children under 6 months of age, 13.8 minutes ( $\mathrm{IQR}=11.3$ ) from 6 to 11 months, 15.6 minutes ( $\mathrm{IQR}=12.8)$ from 12 to 23 months, and 15.0 minutes $(\mathrm{IQR}=12.9)$ in children 24 months or older.

The total number of foods from the 24HRs was 188,046, repeated in 2,023 foods. Of these, 277 were not part of the 24HR-App database. However, analysis of the foods' description showed that 216 items either had spelling errors (e.g., "porrige" instead of "porridge"), the word order was inverted (e.g., "orange natural juice" instead of "natural orange juice"), or there were similar foods. The number of effectively new foods was thus 61 of the 2,023 foods included (3\%). The rate of lack of completion for each of the variables "preparation", "addition", and "meal place" was $2 \%$. The list of frequency of "amounts" allowed identifying incomplete items $(1.1 \%, \mathrm{n}=2,601)$ and keying-in errors $(0.7 \%, \mathrm{n}=$ 
1,388). Analysis of the "observations" field allowed clarifying doubts and resolving incomplete items related to the foods' details. As for the "unit", among all the foods in the database, 58,996 (31.3\%) had their units reported as one of the photos in the photographic manual, showing that this material was frequently used to quantify the child's dietary intake.

\section{Discussion}

The data collection methods on feeding practices and dietary intake in children under five years of age in the ENANI-2019 followed the recommendations on the topic 15,21. Their strengths were developing the 24HR-App and the photographic manual and the quality control strategies while still out in the field, which allowed timely identification of the problems and intervention to improve data recording.

An important advantage to the App's use was the standardization of data collection, minimizing errors associated with this instrument and providing inter-interviewer consistency on foods and portions. Considering that $24 \mathrm{HR}$ was a new method for the interviewers, it was essential to guarantee training with sufficient time for their familiarity with the technique and practical experience with the application and use of the 24HR-App. The App was designed in a user-friendly format, confirmed by the interviewers after the training sessions. According to the Executive Committee of ENANI-2019, the main problems detected in the field involved the individual interviewer's limited engagement in the activity rather than the limitations in the App or the backup materials. Thus, improvements can be introduced, such as modifying the keypad and implementing data entry control mechanisms. The 24HR-App, made available via free access by other professionals, streamlines and upgrades the data collection stage in studies and will allow comparability between dietary intake studies.

The developed photographic manual was a tool that provided more options to report amounts consumed by the child and inspired considerable interest among the interviewees, according to the interviewers. In addition, having been elaborated according to international guidelines, the manual is a legacy for other under-five dietary intake surveys, and potentially for use in the primary healthcare network.

Both instruments used in the ENANI-2019 survey will generate the indicators recommended by WHO 15 and the Brazilian Food and Nutritional Surveillance System (SISVAN) 31 and expand knowledge on feeding practices in young children in the country. Meanwhile, the fact that the 24HR was not replicated in a subsample due to the high cost and logistic difficulties related to the interviewer's return visit to the household was the main methodological limitation in this component of the ENANI-2019 survey. Furthermore, a single 24HR does not allow correcting the distribution of dietary intake according to intrapersonal variability 32,33 , which limits obtaining data on the prevalence of inadequacy/toxicity of children's dietary intake 33,34. However, it allows for comparison of mean intake levels between subgroups or strata in sample 34,35 . This limitation can be minimized by creating correction factors based on databases from studies in which the target group is similar to that of ENANI-2019.

\section{Final remarks}

The information obtained from the questionnaire on under-five feeding practices and the $24 \mathrm{HR}$ will allow studying the children's dietary profile and the information from the other domains of the ENANI-2019 survey, understanding their relationship to anthropometric nutritional status and micronutrient deficiencies. The evidence on dietary intake will provide unprecedented results at the national level in Brazil. It can back public policies to improve feeding practices in children under five years of age. 


\section{Contributors}

E. M. A. Lacerda, C. S. Boccolini, N. H. Alves-Santos, I. R. R. Castro, L. A. Anjos, S. P. Crispim, T. H. M. Costa, M. M. M. Ferreira, D. R. Farias, and G. Kac contributed to the study conception and design, and to the article's writing and review. L. B. V. Carneiro and T. L. Berti contributed to the article's writing and review. All authors approved the final version of the article.

\section{Additional informations}

ORCID: Elisa Maria de Aquino Lacerda (00000002-1830-4278); Cristiano Siqueira Boccolini (0000-0002-4804-5641); Nadya Helena Alves-Santos (0000-0002-0098-6047); Inês Rugani Ribeiro de Castro (0000-0002-7479-4400); Luiz Antonio dos Anjos (0000-0002-5257-6912); Sandra Patricia Crispim (0000-0002-2257-9899); Teresa Helena Macedo da Costa (0000-0002-3396-5058); Milena Miranda de Moraes Ferreira (0000-0002-26524051); Dayana Rodrigues Farias (0000-0003-02788375); Leticia Barroso Vertulli Carneiro (00000003-0832-2293); Talita Lelis Berti (0000-00031160-3512); Gilberto Kac (0000-0001-8603-9077).

\section{Acknowledgments}

To Rafael Claro, Ana Amélia Vilela, Maria Beatriz Castro, Muriel Gulbert, and Ianna Lobo for their collaboration in the planning of the research. To the institutions that allowed the central training to be carried out on their premises. To Paula Normando, Maiara Freitas, Neilane Bertoni, Raquel Schincaglia, Pedro Gomes, Juliana Mello, Ana Beatriz Rodrigues, and Letícia Ramos for their support in the organization of the database. To Bernadette Franco, Eliana Giuntini, and Kristy Coelho for their collaboration in the elaboration of the food composition database.

\section{References}

1. United Nations Children's Fund. The State of the World's Children 2019. Children, food and nutrition: growing well in a changing world. New York: United Nations Children's Fund; 2019.

2. Victora CG, Bahl R, Barros AJ, França GV, Horton S, Krasevec J, et al. Breastfeeding in the 21st century: epidemiology, mechanisms, and lifelong effect. Lancet 2016; 387:475-90.

3. Lamberti LM, Zakarija-Grković I, Fischer Walker CL, Theodoratou E, Nair H, Campbell $\mathrm{H}$, et al. Breastfeeding for reducing the risk of pneumonia morbidity and mortality in children under two: a systematic literature review and meta-analysis. BMC Public Health 2013; 13 Suppl 3:S18.

4. Roth DE, Caulfield LE, Ezzati M, Black RE. Acute lower respiratory infections in childhood: opportunities for reducing the global burden through nutritional interventions. Bull World Health Organ 2008; 86:356-64.

5. Park S, Pan L, Sherry B, Li R. The association of sugar-sweetened beverage intake during infancy with sugar-sweetened beverage intake at 6 years of age. Pediatrics 2014; 134 Suppl 1:S5662.

6. Grimm KA, Kim SA, Yaroch AL, Scanlon KS. Fruit and vegetable intake during infancy and early childhood. Pediatrics 2014; 134 Suppl 1:S63-9.

7. Boccolini CS, Boccolini PMM, Monteiro FR, Venâncio SI, Giugliani ERJ. Tendência de indicadores do aleitamento materno no Brasil em três décadas. Rev Saúde Pública 2017; 51:108.

8. Jaime PC, Frias PG, Monteiro HOC, Almeida PVB, Malta DC. Healthcare and unhealthy eating among children aged under two years: data from the National Health Survey, Brazil, 2013. Rev Bras Saúde Mater Infant 2016; 16:149-57.

9. Jaime PC, Prado RR, Malta DC. Family influence on the consumption of sugary drinks by children under two years old. Rev Saúde Pública 2017; 51 Suppl 1:13s.

10. Rinaldi AEM, Conde WL. A influência das informações da Pesquisa Nacional de Saúde sobre a estimativa atual e a trajetória do aleitamento materno exclusivo no Brasil. Cad Saúde Pública 2019; 35:e00190118.

11. Vasconcellos MTL, Silva PLN, Castro IRR, Boccolini CS, Alves-Santos NH, Kac G. Sampling plan of the Brazilian National Survey on Child Nutrition (ENANI-2019): a populationbased household survey. Cad Saúde Pública 2021; 37:e00037221.

12. Alves-Santos NH, Castro IRR, Anjos LA, Lacerda EMA, Normando P, Freitas MB, et al. General methodological aspects in the Brazilian $\mathrm{Na}$ tional Survey on Child Nutrition (ENANI-2019): a population-based household survey. Cad Saúde Pública 2021; 37:e00300020. 
13. Anjos LA, Ferreira HS, Alves-Santos NH, Freitas MB, Boccolini CS, Lacerda EMA, et al. Methodological aspects of the anthropometric assessment in the Brazilian National Survey on Child Nutrition (ENANI-2019): a populationbased household survey. Cad Saúde Pública 2021; 37:e00293320.

14. Castro IRR, Normando P, Alves-Santos NH, Bezerra FF, Reis MC, Pedrosa LFC, et al. Methodological aspects of the micronutrient assessment in the Brazilian National Survey on Child Nutrition (ENANI-2019): a population-based household survey. Cad Saúde Pública 2021; 37:e00301120.

15. World Health Organization; United Nations Children's Fund. Indicators for assessing infant and young child feeding practices. Definitions and measurement methods. Geneva: World Health Organization; 2021.

16. Oliveira JM, Castro IRR, Silva GB, Venancio SI, Saldiva SRDM. Avaliação da alimentação complementar nos dois primeiros anos de vida: proposta de indicadores e de instrumento. Cad Saúde Pública 2015; 31:377-94.

17. von Seehausen MP, Oliveira MIC, Boccolini CS, Leal MC. Fatores associados ao aleitamento cruzado em duas cidades do Sudeste do Brasil. Cad Saúde Pública 2017; 33:e00038516.

18. Meneses TMX, Oliveira MIC, Boccolini CS. Prevalence and factors associated with breast milk donation in banks that receive human milk in primary health care units. J Pediatr (Rio J.) 2017; 93:382-8.

19. Boccolini CS, Pérez-Escamilla R, Giugliani ER, Boccolini PM. Inequities in milk-based prelacteal feedings in Latin America and the Caribbean: the role of cesarean section delivery. J Hum Lact 2015; 31:89-98.

20. Baranowski T. 24-h recall and diet record methods. In: Willett W, editor. Nutritional epidemiology. 3rd Ed. Oxford: Oxford University Press; 2013. p. 49-69.

21. Moshfegh AJ, Rhodes DG, Baer DJ, Murayi T, Clemens JC, Rumpler WV, et al. The US Department of Agriculture Automated MultiplePass Method reduces bias in the collection of energy intakes. Am J Clin Nutr 2008; 88:32432.

22. Crispim SP, Kac G, Lacerda EMA, Castro IRR. Manual fotográfico de quantificação alimentar infantil. Curitiba: Universidade Federal do Paraná; 2018.

23. Instituto Brasileiro de Geografia e Estatística. Pesquisa de Orçamentos Familiares 2008-2009: análise do consumo alimentar pessoal no Brasil. Rio de Janeiro: Instituto Brasileiro de Geografia e Estatística; 2011.
24. Crispim SP, Nicolas G, Knaze V, Freisling H, Slimani N. Reference guidelines for the preparation of photos for food portion quantification in EPIC-Soft. Lyon: International Agency for Research on Cancer/World Health Organization; 2014.

25. Kimberlin CL, Winterstein AG. Validity and reliability of measurement instruments used in research. Am J Health Syst Pharm 2008; 65:2276-84.

26. Camenzind-Frey CZ. menuCH -Schweizerisches Fotobuch/Livre Photo Suisse/Manuale Fotografico Svizzero. Bern: Bundesamt für Gesundheit und Bundesamt für Lebensmittelsicherheit und Veterinärwesen; 2014.

27. French Agency on Food, Environmental and Occupational Health and Safety. Picture book for the estimation of food portion sizes for the French food consumption survey INCA3. Maisons-Alfort: French Agency on Food, Environmental and Occupational Health and Safety; 2013.

28. Instituto Brasileiro de Geografia e Estatística. Pesquisa de Orçamentos Familiares 2008-2009: tabela de medidas referidas para os alimentos consumidos no Brasil. Rio de Janeiro: Instituto Brasileiro de Geografia e Estatística; 2011.

29. Pinheiro A, Lacerda E, Benzecry E, Gomes M, Costa V. Tabela de avaliação de consumo alimentar em medidas caseiras. $5^{\text {th }}$ Ed. Rio de Janeiro: Atheneu; 2008.

30. Universidade de São Paulo. Tabela brasileira de composição de alimentos. Versão 7.0. São Paulo: Universidade de São Paulo; 2019.

31. Ministério da Saúde. Orientações para avaliação de marcadores de consumo alimentar na atenção básica. Brasília: Ministério da Saúde; 2015.

32. Beaton GH, Milner J, Corey P, McGuire V, Cousins M, Stewart E, et al. Sources of variance in 24-hour dietary recall data: implications for nutrition study design and interpretation. Am J Clin Nutr 1979; 32:2546-59.

33. Carriquiry AL. Estimation of usual intake distributions of nutrients and foods. J Nutr 2003; 133:601S-8S.

34. Dodd KW, Guenther PM, Freedman LS, Subar AF, Kipnis V, Midthune D, et al. Statistical methods for estimating usual intake of nutrients and foods: a review of the theory. J Am Diet Assoc 2006; 106:1640-50.

35. Food and Agriculture Organization. Dietary assessment: a resource guide to method selection and application in low resource settings. Rome: Food and Agriculture Organization; 2018. 


\section{Resumo}

Este artigo tem o objetivo de descrever aspectos metodológicos, operacionais e de controle de qualidade referentes à avaliação do consumo alimentar de crianças menores de 5 anos participantes do Estudo Nacional de Alimentação e Nutrição Infantil (ENANI-2019), inquérito domiciliar realizado em amostra probabilística de domicílios brasileiros. Foram desenvolvidos dois instrumentos para a avaliação de práticas de alimentação infantil: um questionário estruturado, do tipo current status, e um recordatório alimentar de 24 horas (24HR), ambos instalados em um dispositivo móvel de coleta de dados, utilizados por entrevistadores previamente treinados. Também foi elaborado o Manual Fotográfico de Quantificação Alimentar Infantil, que foi usado como apoio para a identificação e quantificação dos alimentos referidos no 24HR. Durante o trabalho de campo, foi realizado controle de qualidade dos registros de forma contínua. Erros de coleta ou incompletudes no sistema eram corrigidos imediatamente e a equipe de campo era sistematicamente contatada e informada sobre o seu desempenho, sendo reiteradas orientações de coleta de dados. Todas as crianças da amostra foram avaliadas usando-se os dois instrumentos, sendo obtidos dados referentes ao questionário estruturado de todas as 14.558 crianças que constituíram a amostra e ao $24 H R$ de 14.541 crianças. O ENANI-2019 desenvolveu métodos e materiais inovadores baseados na literatura nacional e internacional para avaliar lacunas de conhecimento sobre o consumo alimentar infantil. Resultados inéditos serão produzidos, o que permitirá atualizar as diretrizes de alimentação $e$ nutrição voltadas para crianças menores de 5 anos no Brasil.

Alimentos; Lactente; Criança; Lactancia Materna; Inquéritos sobre Dietas

\section{Resumen}

El objetivo de este artículo es describir aspectos metodológicos, operacionales y de control de calidad, referentes a la evaluación del consumo alimentario en niños menores de cinco años, participantes en el Estudio Nacional de Alimentación y Nutrición Infantil (ENANI-2019), encuesta domiciliaria realizada en una muestra probabilistica de domicilios brasileños. Se desarrollaron dos instrumentos para la evaluación de prácticas de alimentación infantil - un cuestionario estructurado, tipo current status, y un recordatorio alimentario de 24 horas (24HR), ambos instalados en un dispositivo móvil de recogida de datos, utilizados por entrevistadores previamente entrenados. También se elaboró el Manual Fotográfico de Cuantificación Alimentaria Infantil, que se utilizó como apoyo para la identificación y cuantificación de los alimentos referidos en el $24 \mathrm{HR}$. Durante el trabajo de campo, se realizó un control de calidad de los registros de forma continua. Errores de recogida o incompletitudes en el sistema eran corregidos inmediatamente, y el equipo de campo era sistemáticamente contactado e informado sobre su desempeño, siendo reiteradas las orientaciones de recogida de datos. Todos los niños de la muestra fueron evaluados usando los dos instrumentos, obteniéndose datos referentes al cuestionario estructurado de cada uno de los 14.558 niños que constituyeron la muestra y al $24 \mathrm{HR}$ de 14.541 niños. El ENANI-2019 desarrolló métodos $y$ materiales innovadores, basados en la literatura nacional e internacional, para evaluar lagunas de conocimiento sobre el consumo alimentario infantil. Se producirán resultados inéditos, lo que permitirá actualizar directrices de alimentación y nutrición, dirigidas a los niños menores de cinco años en Brasil.

Alimentos; Lactante; Niño; Aleitamento Materno; Encuestas sobre Dietas
Submitted on 18/Oct/2020

Final version resubmitted on $03 / \mathrm{Feb} / 2021$

Approved on 02/Mar/2021 